\title{
GONDOLATOK A MÚEMLÉK ÉPÜLETEK ÉS MŰKINCSEK SZERKEZETI ANYAGAIRÓL ÉS ANYAGAIK SZERKEZETÉRŐL
}

\section{THOUGHTS ABOUT THE STRUCTURAL MATERIALS AND MATERIAL STRUCTURE OF HISTORIC BUILDINGS AND MONUMENTS}

\author{
Kopenetz Lajos ${ }^{1}$, Gobesz F.-Zsongor ${ }^{2}$ \\ Kolozsvári Müszaki Egyetem, Épitömérnöki Kar, Tartószerkezetmechanikai Tanszék, \\ Cím: 400020, Románia, Kolozsvár, C. Daicovicu (Bástya) u. 15; Telefon: +40-264- \\ 401351,1 ludovic.kopenetz@mecon.utcluj.ro, 2go@mecon.utcluj.ro
}

\begin{abstract}
The maintenance and the repair of historic buildings and monuments will require in many situations structural interventions. In such cases the study of the structure is not enough, the materials must also be known. Ignoring the compatibility issues can lead to significant damage in terms of preserving. Beside different types of stones, bricks and binders, metal and wood elements are often parts of such structures. The proper knowledge of the properties of these materials, combined with the right structural solutions can ensure the integrity of our built heritage.
\end{abstract}

Keywords: heritage building, monument, structure, material.

\section{Összefoglalás}

A müemlék épületek és mükincsek karbantartása és javítása sok esetben szerkezeti beavatkozásokat tesz szükségessé. Ilyen esetekben nem elég a tartószerkezet vizsgálata, az anyagokat is ismerni kell. Az összeférhetőségi kérdések figyelmen kívül hagyása jelentős károsodáshoz vezethet állagvédelem szempontjából. A különféle kőfajták, téglák és kötőanyagok mellett, fém és fa elemek is gyakran szerepelnek ilyen tartószerkezetben. Ezen anyagok jellemzőinek a megfelelő ismerete, helyes szerkezeti megoldásokkal ötvözve biztosíthatja épített örökségünk épségét.

Kulcsszavak: müemlék, mükincs, szerkezet, anyag.

\section{Bevezetés}

A müemlék szerkezetek és mükincsek után az érdeklődés jelentős az egész világon. Ehhez hozzájárul, hogy ezek a történelmi és müvészi emlékek hatalmas turista attrakciót képviselnek, tehát gazdasági erőforrást is jelentenek. Az ilyen tartószerkezet konzerválásának, restaurálásának a megválasztásánál az építési anyag fajtája és minő- sége szorosan kötődik, ezért a funkció és a forma mellett figyelembe kell venni. Így, a kiemelten fontos müemlék tartószerkezetek, falazatok, pillérek, boltozatok karbantartása és helyreállítása sok körültekintést igényel. A statikai mérlegelés és számítások során különös figyelmet kell fordítani az összeférhetőségi kérdésekre a meglévő szerkezeti anyag és a megerősítő szerkezet között.

A tartószerkezet felújítási tervezési menete általában követi a többi mérnöki terve- 
zés menetét (koncepció és elvi kialakítás tanulmányok meg változatok alapján, megvalósíthatósági vizsgálat, általános terv, engedélyezési terv, kiviteli tervek). A müemlékek anyagának kutatására sajnos a magyar szaknyelvben nincs egy egységesen elfogadott szakkifejezés. A német szaknyelv „Bauforschung” elnevezést használ e célra, a magyarban „falkutatatás” vagy „épületkutatás” a jelenleg használtabb [1].

A müemlék épületek és mükincsek korszerủ felújítása egy alapos és átfogó anyagismereti kutatás mellett megköveteli ezeknek az anyagoknak az épületszerkezetbeli jelenlétének az ábrázolását és viselkedésük ismeretét. Ezeket az igényeket csak úgy lehet elérni, ha a feltárási, falkutatási szakértők átvesznek módszereket a restaurátori technikákból.

\section{A műemlékek és mükincsek szerkezeti anyagai}

Az erőtani számításoknál, úgy szerkezeti, mint anyag-modellek is szükségesek. Az anyag-modellek fejlődésében nagy szerepet játszottak a múlt század elején érvénybe lépő szerkezeti szabályzatok, a szerkezeti modellek fejlődése viszont ezt jóval megelözte. A méretezési alapelvek között is jelentős különbségek vannak. Míg a szerkezeteknél a determinisztikus elmélet és szemlélet a jellemző, addig az anyagok esetében a sztochasztikus alapokon nyugvó módszereken van a hangsúly. A szerkezetek nem ismerik ezeket az elméleteket és a valóságban, mint mindenhol a természetben, az öntörvényeik szerint viselkednek.

A mủemlékek és mükincsek esetében az anyagtani problémák szorosan kapcsolódnak az építési kronológiához, az építési és átalakítási periódusok szétválasztásával együtt. Az új szerkezetekhez használt építőanyagok jól meghatározott anyagjellemzőivel szemben a müemlék épületeknél és mükincseknél kevés anyagminta alapján becsült tervezési paramétereket veszünk ala- pul. Ilyen esetekben nem alkalmazhatók egyértelmüen az érvényes szabványok, a lassú hatások nagymértékben megváltoztathatják a szerkezeti analízishez használt alapadatok nagyságrendjét, ha a felújitás alatt a szerkezet meglévő egyensúlyán a funkció változása ilyen irányba hat.

A műemlék építmények részei (az alapozás, földszinti padlószerkezet, külső és belső falak, lépcsők, közbenső födémek) szinte kivétel nélkül építőelemként a követ és a téglát tartalmazzák, kötőanyaggal egymáshoz rögzítve. A mészkő, homokkő, andezit, bazalt, trachit, riolit és a tufák a leginkább használt kőfajták [2]. A téglák anyaga olyan agyag, melyben a mésztartalom nem haladja meg a $10 \%$-ot. Kötőanyagként, a kötések típusa szerint csoportosítva, a következő anyagok találhatók:

- agyag és vályog (száradás után kötnek);

- mész, mészhidrát és gipsz (levegőn szilárduló kötőanyagok);

- hidraulikus mész, cementek és habarcsok

(levegőn és vízben szilárduló, vagy hidraulikus kötőanyagok).

Szerkezeti szempontból a legfontosabb kötőanyag a hidraulikus mész (már a rómaiak is használták). Szárazon vagy vízben egyaránt megkeményedik, $\mathrm{s}$ a szilárdulás után a vízben oldhatatlan. Az előállításához a márgát (10-20\%-os agyagtartalmú meszet) $1100-1200{ }^{\circ} \mathrm{C}$-ra hevítik fel [3]. Mivel a szilárdsága megnő a kötés befejezése után (úgy a levegőn, mint a vízben), nagyon megfelelő az alkalmazása olyan szerkezeteknél, amelyeket később nedvesség érhet. Ezt az anyagot használták Cézár és Augustus korában is, de Vezúv környéki tufával keverve, emiatt az így kapott anyagot később római cementnek nevezték el. Ilyen fajta cementtel épült a budapesti Lánchíd alapja is 1840-ben. A múemlékeknél alkalmazott habarcsok alkotórészei a következők [4]:

- kötőanyag (mész, hidraulikus mész, trasz, gipsz); 
és anyagaik szerkezetéröl

- adalék (5 mm-nél kisebb szemcséjü homok, vagy kőzúzalék).

Aspdin (1824) az általa elóállított „Portland cement”-nél mesterséges keveréssel próbálta a márga hatását biztosítani, de az összetevők 10\%-át meghaladó oldódó sók kristályosodási folyamatokat okoznak a nedvesség hatására, amik a veszélyes betonkorrózió alapját képezik [5]. A „Portland cement" megjelenése után sok hibát és gondot okozott, hogy a müemlék épületeknél a habarcsokhoz (különösen vakolóhabarcsokhoz) alkalmazták.

Az egyik legnagyobb gond a müemlék szerkezeti anyagok elhasználódása, amely az öregedés, túlterhelés, kifáradás, korrózió vagy kopás külön vagy kölcsönös befolyása hatására áll elő. Ez az elhasználódás a koros épületek esetében nagymértékben természetes jelenség. Általában nem egy, hanem több oka is van, s ezek kölcsönösen befolyásolhatják egymást. A mechanikai elhasználódás általában a tartós húzó, nyomó, rezgő vagy ütő igénybevételek miatt jelentkezik, illetve a korrózió vagy a kopás miatt. A szimptómák a következők:

- rugalmasság csökkenése és képlékeny alakváltozások megjelenése;

- elmozdulási, alakváltozási érzékenység kis tehernövekedésre;

- törés, teherbíró-képesség eltünése és az épületszerkezet szétválása;

- mechanikai instabilitás;

- újrakristályosodás;

- fázisátalakulás.

Amikor a természeti törvényszerüségröl beszélünk, elkerülhetetlen a szerkezeti tervezésben arra az alapvető jelenségre rámutatni, hogy a természet mindenkor a legkisebb erőfordítással törekszik az egyensúlyi állapotra. Torroja Eduardo profeszor (a „Philosophy of Structures” címü könyvében) e gondolatot úgy fogalmazta, hogy „törekedni kell az anyag minimális igénybevételére". Ez az állítás akkor látszik igazán valónak, amikor arra gondolunk, hogy hányszor fordul elő olyan eset amikor statikailag nem bizonyítható szerkezetek állva maradnak, mert ki nem használt szerkezeti részeik egymást segítik. A lényeg te-hát, a müemléki szerkezeteknél is, az alap-vető strukturális elképzelés, míg a statikai modell és a méretezési eljárás csupán esz-köz. A tervezési módszereket sem lehet feltétel nélkül megbízhatónak tekinteni.

\section{Az anyagok szerkezeti kérdései}

A müemlékek és mükincsek, mint müszaki mesteri alkotások, a mesterségbeli tudás és ráérzés magas fokú eredményei. A nagy lélegzetủ müemlék szerkezetek és mükincsek szerzői a szerkezeti anyag belső feszültségállapotát, tulajdonságait és törvény-szerüségeit kitünően ismerő mesterművészek voltak, $\mathrm{s}$ ma is azok.

$\mathrm{Az}$ anyagszerkezet kutatása igyekszik tisztázni az anyagok belső szerkezetét és viselkedését. A jelenlegi anyagszerkezeti kutatásokat ki kell bővíteni archeometriás módszerekkel. A földben rejlő épületmaradványok, üregek döntően befolyásolhatják a müemlék szerkezeti viselkedését, így szükség van a földnek is mint anyagnak a kutatására. A szokásos szondázási, fúrási mód-szerek nagyon költségesek és nem alkalmasak egy átfogó jelentés elkészítésére. Az ilyen vizsgálatokra megfelelőbbek a következő felderítési módszerek:

- mágneses leletfelderítés és elektromágneses módszerek;

- ellenállásmérésen alapuló módszerek;

- akusztikus módszerek;

- radar és légi felvételek kiértékelése;

- víz alatti lelet-felderítési módszerek.

E módszerek közül az ellenállásmérésen alapulóknak van a legnagyobb jövője. Minden talaj vezeti az elektromos áramot, fajtája, nedvessége és sótartalma függvényében, az építészeti maradványok és létező üregek (elhagyott pincék, alagutak) hatására a vezetőképesség (ellenállás) megváltozik. A különböző távolságokra, mélységekre he- 
lyezett elektródák között folyó áram erőssége és feszültség-esése a különböző földalatti alapokról, üregekről ad egy kezdeti képet.

A vasat használó szerkezeteknél nagyon fontos a vasfajta típusának a pontos megállapítása. A nyersvas (mintegy 4\%-os széntartalommal) lehet fehér nyersvas (itt a szén vas-karbidként szerepel) vagy szürke nyersvas (ahol a szén grafitként is jelen van). Az öntöttvas a $2 \%$-nál kisebb széntartalommal (grafitként) önthető, de nem kovácsolható, hegeszthetö, míg a hasonló széntartalmú kovácsoltvas (lágy-vas), mint neve is mondja, kovácsolható. Az 1,5-2\%os széntartalmú acél önthető és kovácsolható. A vasnak, mint anyagnak a kutatásánál nagyon előnyös a csiszolatok metallográfiás vizsgálata, amivel meg lehet állapítani precízen a vas széntartalmát és keménységméréseket is lehet végezni. Az ólom az épületszerkezeteknél (föleg kő-oszlopoknál és kőfalaknál) mint kapcsoló elem található (elsősorban öntéssel dolgozták és dolgozzák fel. Ezek a kapcsoló elemek nagyon fontosak a földrengésvédelem szempontjából és az anyag vizsgálata szigorúan a metallográfiás módszereket kell kövesse.

A szerkezeti kő az egyik legfontosabb és legrégebben használt anyag, úgy épületszerkezetekhez, mint szobrok készítéséhez is. Petrográfiailag nagyszámú kőféleséget használtak (magmás, eruptív és üledékes kőzeteket). A metamorf kőzetek (márvány, gnejsz, stb.) a magas nyomás és hőmérséklet hatására jöttek létre és általában magmás vagy üledékes eredetűek. Az anyagi vizsgálatokhoz a mikroszkópos és vékonycsiszolatos módszert alkalmazzák elsősorban. Kémiai módszereket is lehet használni a kövek jellemzésére, röntgenfluoreszcens, atomabszorbciós, neutroaktivációs analízist és mágneses rezonanciaspektroszkópiát a szén és oxigénizotópok meghatározására. A téglákat (durvakerámia) agyagból állítják elö. Az agyagokban levő vasvegyületek színezik az alapanyagot sárgára, barnára vagy vörösre. A vizsgálatra általában a köveknél használt módszereken kívül, termolumineszcens analízist és atommaghasadás nyomelemzést használnak kormeghatározásra. A téglák szilárdságára és időbeli változására nagyon fontos az égetési hömérséklet ismerete, amit diatometriás galttal lehet megkapni.

A fánál, mint szerkezeti anyagnál, nagyon fontos a fajta megállapítása. A mikroszkópos vizsgálat megfelel és keresztmeg érintő-irányú metszettek alapján készül. A kormeghatározáshoz a radiókarbon módszer javasolható.

\section{Következtetések}

A müemlék szerkezetekkel és mükincsekkel kapcsolatban, manapság a tervező bekapcsolódik általában a kivitelezési tevékenységekbe is, mint tervezői müvezető (ez a nagyon bonyolult tervek esetében szinte nélkülözhetetlen). Ekképp gyorsan megoldódhatnak a szerkezeti anyag és a célelérési technológiák összefüggései, valamint a tervváltoztatások hatásai a szerkezetre, illetve a hatályos elöírások alól való felmentés a biztonság javára.

A műemlék szerkezetek és mükincsek, még ha több száz-, ezerévesek is, fenntartásra, megóvásra várnak. Az egyedi anyagok és szerkezetek megörzése, védelme és fenntartása jogilag a tulajdonos feladata lenne, de valójában mindnyájunké.

\section{Szakirodalmi hivatkozások}

[1] Haris, A.: Müemlék épületek kutatásának módszertana és annak változása, Müemlékvédelem, XLVIII. Évf., 2004, 5. szám, 297.302. old.

[2] Farmer I. W.: Engineering Properties of Rocks, Spon, London, 1968.

[3] Wesche K.: Baustoffe für Tragende Bauteile, Bauverlag Gmbh, Wiesbaden \& Berlin, 1974.

[4] Wagner H.: Taschenbuch Des Chemischen Bautenschutzes, Wissenschaftliche Verlagsgesellschaft, Stuttgart, 1956.

[5] Csekő Gy., Novák A., Száva I.: Betonok és falazatok korrózióvédelme, Műszaki Könyvkiadó, Budapest, 1987. 